\title{
The College English Paperless Teaching Reform
}

\author{
Caiyun Zhang \\ School of Foreign Languages \\ Yan'an University \\ Yan'an , Shaanxi, 716000
}

\begin{abstract}
The continuous development of digital technology and information technology has promoted the reform of education. It has injected a lot of fresh elements into college English teaching and accelerated the process of English teaching reform. Meanwhile, it also has played a very positive role in stimulating students' interest in learning and improving classroom teaching efficiency. So in recent years, there are growing calls for college English "paperless" teaching reform. The paper analyzes the importance of "paperless" teaching reform in college English teaching, and explores the main problems in "paperless" teaching reform, and puts forward some pertinent reform strategies. With them, the efficiency of college English teaching will be improved, and college students' learning interest and enthusiasm will be fully stimulated in the English class so as to so as to achieve a multiplier effect of teaching and learning.
\end{abstract}

Keywords-College English; Paperless; Teaching Reform; strategies

\section{INTRODUCTION}

With the development of modern information education technology, multimedia teaching in college English classroom has been very mature, which lays a good foundation for college English paperless teaching reform. The so-called paperless teaching refers to a new teaching mode which uses multimedia technology and network technology to replace the traditional books and chalk teaching methods. ${ }^{[1]}$ The practice of college English teaching proves that paperless teaching can make up a lot of deficiencies in the traditional English teaching mode in college English teaching reform process, and improve students' English learning interest and enthusiasm. Therefore, it has great practical significance to the promotion of college English teaching reform.

\section{The GREAT SignifiCANCE OF CONDUCTING COLlEGE ENGLISH PAPERLESS TEACHING REFORM}

First of all, college English paperless teaching reform is a great saving of paper resources, especially that with the increasing of English teaching media resources, it is easy to achieve the rapid reproduction, transfer and sharing of English teaching resources, which forms an effective substitute of the traditional English textbooks, review materials, exercises and other paper educational resources, reducing the production of paper and pollution emissions in the paper making process.

Second, college English paperless teaching reform effectively saves teachers' energy in the English classroom by reducing the writing on the blackboard, improving the efficiency of teaching. It improves the efficiency of students via a variety of "human-computer interaction", and expands the contact surface of English knowledge learning. Especially the emergence of a variety of media education resources greatly stimulates students' interest in learning, bringing students an unprecedented learning experience.

Third, college English paperless teaching reform has promoted the construction of harmonious college English classroom, created a more humane learning environment for college students to learn English, and promoted the improvement of teachers' and students' informationization quality and ability; at the same time, the increase of paperless English learning resources and construction of paperless English learning platform provide more convenience for the development of college English autonomous learning activities.

\section{The MAin PROBlems of COLLEGE ENGLiSh PAPERLESS TEACHING REFORM}

\section{A. The Construction of Paperless Teaching Resources is Lagging Behind}

One great advantage of the paperless teaching is that it can fully expand the classroom teaching environment, ${ }^{[2]}$ so that English teaching can really break the limitation of the paper resources such as textbooks, and broaden students' English learning perspective. It can enhance students' English learning autonomy through network independent learning, and use image, sound, video and other forms to present traditional text teaching content. And students can also learn through a variety of terminals. However, in the process of paperless teaching reform, many college English teachers are accustomed to following the script. Their teaching thought is relatively backward. In the application of modern information technology, they pay little attention to the collection and arrangement of English education paperless teaching resources, leading to the lagging behind of the construction of paperless teaching resources and affecting the full play of the advantage of paperless teaching.

\section{B. It Weakens the Interaction of Students in the Classroom}

College English paperless teaching reform process not only enriches the teaching methods of English teachers, but also plays a very good role in supporting teaching. But in the use of paperless resources for lesson preparation, some college English teachers can't handle classroom capacity and teaching content well, which makes teachers and students focus most of their energy on multimedia courseware and other paperless 
educational resources and haven't left enough time and space for interaction. On one side, this is not conducive to ensuring students' dominant role in English classroom; on the other hand, it will reduce students' enthusiasm to learn English, letting paperless teaching deviate from the basic teaching objectives.

\section{Paperless Teaching Model Is Still Out-dated}

At present, although most college English teachers are aware of the importance of paperless teaching, and actively implement paperless teaching reform in the teaching process, they still remain on the basic level such as making multimedia courseware and playing audio and video materials. Therefore paperless teaching model is still relatively backward. With the arrival of the whole media era, information technology teaching means is changing with each passing day. But many college English teachers are accustomed to enclosing students in teaching materials and courseware, completely isolating them from the rich learning resources and realistic situation and letting students remain as passive knowledge receiver and object of knowledge indoctrination. It can be said that the application of paperless educational resources in the English classroom is "a change in form but not in content". It is still a continuation of the traditional teaching model.

\section{College English Teachers' Information Quality Is Low}

The reason that English teachers' teaching effect is not ideal in the paperless teaching reform process is largely because the relatively low computer operating capacity and information quality of English teachers makes teachers not good at the development and application of paperless educational resources, restricting the in-depth development of college English paperless teaching reform. For example, some college English teachers' operating capacity is relatively poor when making multimedia courseware. They usually download ready-made templates from the network, and improve it in accordance with the content of teaching materials, making it hard for students to feel innovative and interested in the class. Therefore, the paper teaching reform can only stay in the initial state, not able to form an effective innovation of the traditional teaching mode.

\section{College English Paperless Teaching Reform STRATEGIES}

\section{A. Classroom Teaching and Training of "Paperless"}

As an important way of college English teaching, information technology teaching method can effectively enhance the openness of college English classroom, and reflect teachers' personality. ${ }^{[3]}$ As the traditional teaching mode is mainly based on "textbooks + chalk + blackboard", it does not have a good environment and atmosphere for oral English teaching. The teaching of English theoretical knowledge also mainly focuses on lexical explanation, text comprehension and grammar knowledge teaching, which is not conducive to the cultivation of college English teaching ability. College English paperless teaching reform can help English teachers to develop personalized teaching programs to achieve the diversification of English classroom teaching methods and expand the depth and breadth of English classroom teaching, greatly enhancing classroom teaching quality and teaching efficiency. Especially the construction of multimedia classroom with English pronunciation and picture function in college has provided more effective help to the training of English listening and speaking skills of college students, and overcame many drawbacks of traditional English teaching.

\section{B. Construction of Sharing and Autonomous English Learning Resources}

To college students, English knowledge learning is not only reflected in basic links such as having a good result in the final exam or successfully passing CET 4 or CET 6. Nowadays college English teachers and students pay more attention to the communication function and instrumental feature of English. A lot of students have treated English as a necessary tool for personal future career development, postgraduate education or studying abroad. Therefore, college students’ English learning needs also become increasingly diversified. At this point, English classroom teaching and training are no longer able to meet students' individual learning needs. Colleges and universities need to actively build network learning platform to accelerate the sharing of paperless educational resources such as English network courses, so as to create better conditions for the independent learning of students. For example, many English teachers have established their own personalized web pages and designed online English listening and speaking training module, so that students can teach themselves through network learning platform.

\section{Online Homework Submission and Correction}

The paperless teaching mode makes the communication and feedback between college English teachers and students become more convenient by breaking the limitation of time and space of students' learning and interaction between students and teachers. It not only allows students learn English knowledge anywhere anytime, but also provides strong technical support for English teachers to monitor and guide students' learning process. For example, teachers can assign college English homework directly online. When answering objective questions, students can use the button to select the answer, and homework correction can be done by the system itself immediately. Students and teachers will get the original score at the same time as the basis of students' further learning or teachers' reform of teaching strategy. When answering open ended subjective questions, teachers can guide students to complete the homework using "Word", which is then directly submitted to the teacher in the system. Teachers can use the "revision "and "remarks " functions in "Word" to correct the homework and save it in the system, which provides a great convenience for the work instruction of teachers and greatly improve their work efficiency.

\section{Construction of Paperless Evaluation System}

Based on the reference of TOEFL and other computerbased test experience, the construction of college English paperless evaluation system is imperative. ${ }^{[4]}$ For example, CET 4 and CET 6 will both gradually realize the transition from manual examination system to computer-based examination 
system, which involves examination database construction, higher examination, network marking and other major module projects. First of all, examination database construction is a basic work. There are two sources of test paper generation, one is "examination papers database" composed of several papers, and the other is "test question bank". Both "examination papers database" and "test question bank" can be established in batches in four semesters in accordance with current "college English" teaching arrangements. Second, the construction of test system requires a human-computer interaction interface to facilitate students to read the papers and choose the answer, while avoiding the drawbacks that some of the computer-based test system can only answer in order and can't go back to check and modify. Third, marking system can use machine to read answer sheet when checking objective questions; when checking subjective questions, computer-based text system should have the online subjective questions marking function, which allows several teachers to read over online at the same time, and the scores can be obtained by the weighted average of the scores of more than one person.

\section{CONCLUSION}

In summary, college English paperless teaching reform is the inevitable choice of informationized and interactive teaching of higher education. It has become an important trend in the reform of college English teaching and has been sought after by many college English teachers and students. However, in order to improve the effectiveness of college English paperless teaching reform, college English teachers must constantly improve their information quality, correctly position themselves in the paperless classroom, and truly overcome various disadvantages of traditional college English informationized classroom, improve the efficiency of college English teaching, and fully stimulate college students' learning interest and enthusiasm in the English classroom, so as to achieve a multiplier effect of teaching and learning.

\section{REFERENCES}

[1] Xia Jimei, Yang Yi. Candidates Feedback Survey of CET 4 Network Test and Paper Test[J]. Foreign Language Testing and Teaching, 2011, (02).

[2] Chen Yiping. Fully Promote Paperless Teaching Reform[J]. Journal of Guangdong Peizheng University, 2012, (04).

[3] Qiu Guopeng, Zeng Daorong. Paperless Teaching - Digital Technology Based Art and Design Teaching Conception[J]. Journal of Sanming University, 2007, (02).

[4] Lv Cuicui, Wang Guofeng. Network Item Bank Construction Study Based on "New Horizon College English" - Taking Shandong Technology and Business University as an Example[J], Journal of Mudanjiang Educational College, 2010, (03) 